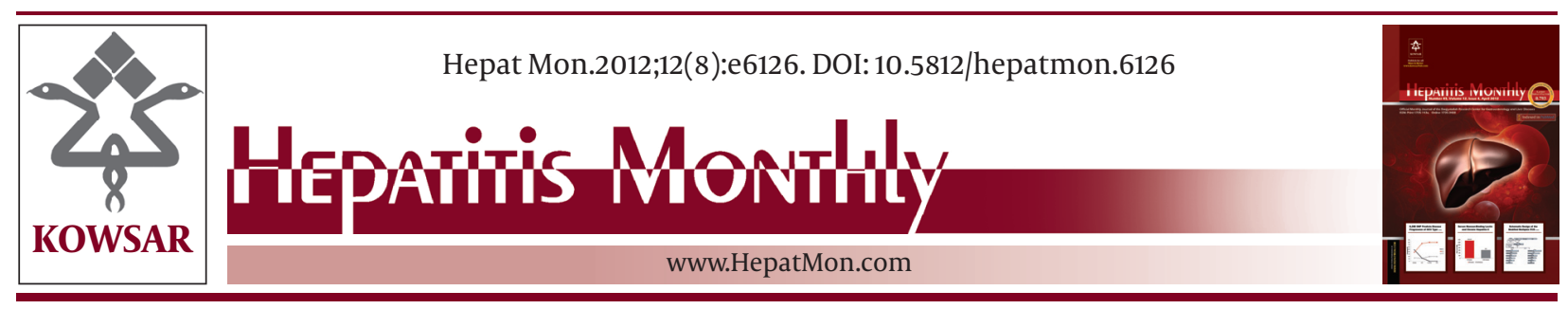

\title{
Occult Hepatitis B (OBH) in Clinical Settings
}

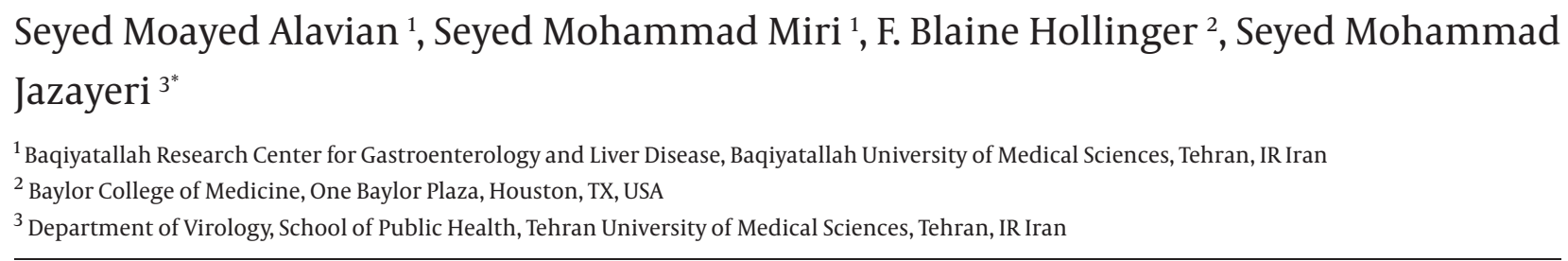

A R T I C L E I N F O

Article type:

Review Article

Article history:

Received: 20 May 2012

Revised: 20 Jun 2012

Accepted: 8 Jul 2012

Keywords:

Hepatitis B

Hepatitis B Surface Antigens

Coinfection

\begin{abstract}
A B S T R A C T
Context: Occult hepatitis B (OHB), or persistent HBV DNA in patients who are hepatitis B surface antigen (HBsAg) negative, is a recently recognized entity. In an attempt to summarize the issues, this review presents an overview of the current proposed hypothesis on the clinical relevance and also updates the knowledge on the classification of OHB in different clinical settings.

Evidence Acquisition: OHB could be found in different population and clinical backgrounds including: viral co-infections (with either human immunodeficiency or hepatitis $\mathrm{C}$ viruses), HBV chronic carriers, dialysis patients, transplantation settings and certain clinical situations (named in here: special clinical settings) with no apparent distinguishable clinical parameters.

Results: The exact magnitude, pathogenesis, and clinical relevance of OHB are unclear. Even the possible role exerted by this cryptic infection on liver disease outcome, and hepatocellular carcinoma development remains unknown.

Conclusions: monitoring of Individuals with positive anti-HBc, mass immunization programs and improvement in diagnostic tools seem to be important to control the probability of transmission of HBV through cryptic HBV infection.
\end{abstract}

Published by Kowsar Corp, 2012. cc 3.0.

Implication for health policy/practice/research/medical education:

Occult HBV infection has received increasing attention in recent years. Although the impact of occult HB in patients has not been determined, it appears to accelerate the progression of liver fibrosis and cirrhosis, ultimately leading to HCC. Occult HBV infection is unexpectedly frequent, in particular in hepatitis C virus (HCV) and in human immunodeficiency virus (HIV) infected individuals. This phenomenon has also been reported in blood transfusion settings. Therefore, OBH has a great impact on public health issues regarding blood safety, HBV diagnosis, etc.

- Please cite this paper as:

Alavian SM, Miri SM, Hollinger FB, Jazayeri SM. Occult Hepatitis B (OBH) in Clinical Settings. Hepat Mon. 2012;12(8): e6126. DOI:10.5812/ hepatmon.6126

\section{Context}

\subsection{Occult Hepatitis B in Clinical Settings}

Occult hepatitis BHBV infection has been documented in a variety of clinical situations, especially among patients who are positive for anti-HBc (Table 1). Occult HBV infection is also commonly present in HCC, chronic hepatitis $C$ virus (HCV) infection $(1,2)$, human immunodeficiency virus (HIV) infection (3), liver-transplant recipients of a liver from a donor who was antibody to the hepatitis B core antigen (anti-HBc) from core-antibody-positive

\footnotetext{
${ }^{*}$ Corresponding author: Seyed Mohammad Jazayeri, Department of Virology, School of Public Health, Tehran University of Medical Sciences, P.O. Box:15155-6446, Tehran, IR Iran. Tel:+98-2188992660, Fax:+98-2188992660, E-mail: jazayerism@tums.ac.ir mits unrestricted use, distribution, and reproduction in any medium, provided the original work is properly cited.
} 
donors (4), hemodialysis patients (5), healthy carriers, patients with cryptogenic advanced liver fibrosis (6), and special high-risk patients.

\section{Evidence Acquisition}

The primary aims of this review were to: first, classify the different aspects of occult hepatitis in terms of clinical classification. Second, to describe the prevalence of $\mathrm{OBH}$ in different clinical settings. Third, to introduce an up to date information regarding the clinical and transmission aspects of $\mathrm{OBH}$. A comprehensive search of PubMed was performed with the following Mesh term search using keyword: occult hepatitis B infection along with keywords: HCV, HIV, Immunosuppression, HCC, transfusion and transplantation. All published data since 2001 (the explanation of OBH) until May 2012 have been included in the study. The inclusion criteria for the study were: all studies that shown the presence of HBV DNA in the absence of HBsAg regardless of antibodies to core and/or surface proteins.

\section{Results}

\subsection{Transfusion Settings}

The blood-safety issues related to the blood components or tissues of HBsAg-negative donors and the risk of transmission are of great concern. Medical researchers fear that OHBI may be spread by blood transfusion because HBV-DNAHBV DNA detection by nucleic acid am- plification technology is not mandatory for blood-donor screening in many countries, especially in those areas where the prevalence of escape mutants is expected to be high. Occult HBV infection may occur in several situations and, as a result, may be transmitted to other individuals through transfusion. Such situations include recovery from infection that leads to the production of anti-HBs but is characterized by persistent low-grade viremia, production of 'escape' mutants that cannot be detected by HBsAg testing, "carriers" with antibody to the hepatitis B e antigen (anti-HBe) and anti-HBc, and carriers that are negative for anti-HBe and anti-HBc. Although all of these situations can raise the transmission of HBV in the immune compromised, only the anti-HBc-positive, HBV-DNA-positive situation is infectious in the immune competent setting. Furthermore, Studies have clearly indicated that transfusion of HBsAg-negative, HBV DNA positive blood donor in blood supply was associated with the development of post-transfusion hepatitis B (7-9). The prevalence of $\mathrm{OHB}$ among HBsAg-negative donors varies in different parts of the world, and as mentioned above, depends on the endemicity of HBsAg carriers as well as the method used to test the virus. Reports from subsets of donors from North America and Western Europe have ranged from as low as $0 \%$ (presence of anti-HBc) $(10,11)$ to as high as $2.8 \%$ (isolated anti-HBc) $(12,13)$. Similarly, studies from Asia (especially from highly endemic regions) have indicated prevalence rates of HBV-DNAHBV DNA detection among blood donors ranging from 0.13 (presence

\begin{tabular}{|c|c|c|}
\hline Clinical Setting & OHB ${ }^{\text {a Prevalence, } \%}$ & Prevalence of OHB in Anti-HBc ${ }^{\text {a }}$ Positive Patients, $\%$ \\
\hline Blood donors ${ }^{b}$ & $0.05-13$ & $0-17$ \\
\hline HIV $^{\mathrm{a}}$ & $0-89$ & $9-44$ \\
\hline $\mathrm{HCV}^{\mathrm{a}}$ & $6.7-91$ & $28-71$ \\
\hline $\mathrm{HCC}^{\mathrm{a}, \mathrm{c}}$ & $12-80$ & $28.8-64$ \\
\hline Immunosuppression & 3.3-37.8 & $37.8-62.3$ \\
\hline Dialysis & $0-58$ & 6.4-64.7 \\
\hline Chronic HBV carriers & $5-55$ & $7-60$ \\
\hline Cryptogenic cirrhosis & $4.8-40$ & $17.8-100$ \\
\hline Transplantation & $36-64$ & $3-100$ \\
\hline Liver & $0-50$ & $4.4-100$ \\
\hline Stem Cell & $0-3.3$ & $3-10$ \\
\hline \multicolumn{3}{|l|}{ Kidney } \\
\hline $\mathrm{HBV}^{\mathrm{a}}$ vaccinated & $2.7-28$ & $6.5-100$ \\
\hline Family contact of HBsAg positive carriers & 8.8- 28.8 & $23.6-96.4$ \\
\hline General Healthy Population $^{d}$ & $0.7-34$ & $6.1-51$ \\
\hline Hemophilia & 5.3-51.2 & $6-100$ \\
\hline
\end{tabular}

a Abbreviations: HBc, hepatitis B core; HBV, hepatitis B virus; HCC, hepatocellular carcinoma; HCV, hepatitis C virus; HIV, human immunodeficiency virus; OHB, Occult hepatitis B.

${ }^{\mathrm{b}}$ The lower and upper limits are in the presence of other serologic evidence and isolated-anti-HBc, respectively.

${ }^{\mathrm{c}}$ No HCV-related HCC.

${ }^{d}$ Highly dependent on the geographic prevalence of HBV. 
of anti-HBc) $(14,15)$ to $8 \%$ (isolated anti-HBc) (16) (Table 1). As in other viral infections, HBV infectivity depends on two main factors: the infectious dose and the immune competence of the host. Considering the volume of infectious material involved in the transfusion of whole blood or a blood component, it is generally accepted that should any HBV DNA be present, infection may occur (even with a viral load of $<20 \mathrm{IU} / \mathrm{mL}$ ) (17). However, some scientists have argued that blood containing anti$\mathrm{HBC}$ with anti-HBs does not appear to transmit HBV components (even through viral loads ranging between 20 and $500 \mathrm{IU} / \mathrm{mL})(8,17)$ if the neutralizing antibody level is sufficiently high.

\subsection{Chronic Carriers}

OHB in apparently healthy HBV chronic carriers is essentially found in four types of clinical conditions: 1) recovery from infection defined by the presence of antiHBs (spontaneous HBsAg seroclearance in a carrier) (18); 2) chronic hepatitis, where the infection is related to escape mutants that are not (or are only poorly) recognized by either natural polyclonal or monoclonal antibodies in the assays (19); 3) low-replicative phase of chronicity at the healthy carriage stage marked by the presence of anti-HBc, with or without detectable antibody to hepatitis B e antigen (anti-HBe) (20); and 4) chronic hepatitis or healthy carriage without any marker of HBV infection other than HBV DNA $(21,22)$, this illustrates the fact that some patients may have had serological markers of HBV infection, but subsequently lost them while still continuing to have a low-grade HBV infection (22). OHB has been described in chronic HBV infection with different outcomes from asymptomatic carriers to HCC patients with genotypes A through $\mathrm{F}$ and $\mathrm{H}$ (23-27). Several authors have investigated $\mathrm{HBV}$ influence, and different $\mathrm{HBV}$ genotypes on OHB prevalence in specific regions. For instance, Weinberger et al. (28) suggested an association between occult HBV infection and genotype D in individuals from Western Europe, where genotype A is more prevalent. However, the findings from a French study did not support this association (29). Cohort studies that include different HBV genotype patients are needed to compare OHB implications in these genetic groups of patients HBV.

\section{3. $\mathrm{HCV}$}

Among 350 million HBV carriers worldwide, the number of individuals with HCV-HBV dual infection is around $5-7$ million. However, it is very likely that the dual HBV$\mathrm{HCV}$ infection prevalence rate is underestimated because occult HBV infection is often not taken into account (30). Since HBV and HCV share many risk factors and the same transmission routes, the high prevalence of occult HBV infection reported in patients with chronic hepatitis C, ranging from $6.7 \%$ to $91.1 \%$, is not surprising $(31,32)$. It is well established in the medical literature that HCV-positive $\mathrm{HCV}$ positive patients exhibit the anti-HBc-alone pattern more often than do HCV-negative HCV negative patients, and anti-HBc reported prevalence in patients with chronic HCV infection ranges from $28 \%$ to $71 \%$ (3335) (Table 1).

These differences in prevalence rates might be responsible for inconsistencies in results on specimen types, recruitment of chronic HCV-infected patients, HBV infection endemicity in the study areas, and study methods in general. One clear example comes from Sagnelly et al. (31) who found prevalence rates of OHB in HCV -infected patients as high as $91.1 \%$ in liver samples compared to just $62.2 \%$ and $32.4 \%$ in PBMC and plasma samples, respectively. Regarding the clinical consequences of occult HBV infection in patients with chronic hepatitis $C$, studies have indicated the negative influence of cryptogenic HBV infection on histologic activity and severity of liver disease and HCC, possibly by integration with the host genome or synthesis of pro-oncogenic proteins by free intrahepatic HBV genomes $(34,36-38)$. Also, in HCV-infected patients, occult HBV infection may contribute to increased plasma HCV-RNA loads and liver transaminase levels (39, 40 ). On the other hand, some studies have reported that OHB occult HBV infection does not affect the pathological findings in the liver, changes in aminotransferase levels, or occurrence of HCC in patients with chronic HCV (32, 41,42 ). It should be noted, however, that all of these studies are cross-sectional, and therefore prospective studies are needed to confirm that occult HBV accelerates liver lesions progression in patients with chronic hepatitis $\mathrm{C}$. Occult HBV infection also might affect the response to antiviral therapy in patients with chronic hepatitis $\mathrm{C}(43$, 44 ), but the available data do not allow any firm conclusions in this regard, partly because of the heterogeneity of the patients enrolled, and the lack of data on care current standards for treatment (45). One study (43) found that HCV patients with occult HBV had lower intrahepatic mRNA levels of IFNAR2 (one of the two subunits of the IFN receptor), which the authors argued was one of the factors that could have led to a poor IFN response. However, the mechanism by which occult HBV may inhibit the patient's response to IFN therapy in chronic hepatitis $\mathrm{C}$ remains unknown and therefore merits further research. Regarding the interaction between different HCV genotypes and OHB, Fukuda et al. (43) observed that patients with occult $\mathrm{HBV}$ infection were more frequently infected by HCV genotype 1a, but this association was not observed in other studies $(32,44)$. Altogether, these data highlight the clinical implications of occult HBV infection in the clinical setting of HCV infection and suggest that screening for OHB should be an essential practice.

\subsection{HIV}

Due to transmission shared modes and risk factors, coinfection with HBV and HIV and even triple infection with HCIV is common. A high HBV DNA prevalence in HBsAgnegative samples from HIV-positive patients indicates 
that HIV infection is a risk factor for OHB (46). Indeed, many reports have indicated that HIV-infected patients are at a higher risk of HBV co-infection in many regions, as illustrated by HBsAg high prevalence in HIV-positive patients in comparison to HIV-negative patients $(47,48)$. The reported prevalence of OHB occult HBV among HIVinfected patients has ranged from $0 \%$ to $89.5 \%$, mostly in anti-HBc positive patients, with a considerable number of other studies reporting results between these two extremes (49-51) (Table 1). The variability between the studies may be explained by fluctuations in HBV-DNAHBV DNA replication over time (even when these assays are validated with high specificity and quite high sensitivity), HCV co-infection, or the impact of treatments that are active against both HIV and HBV, such as lamivudine and tenofovir. In addition, differences in risk factors for contracting HBV between the studied populations and regional differences in overall HBV prevalence may contribute to the observed differences in occult HBV prevalence. Furthermore, such studies suffer from a lack of methodological standardization, limited sample sizes, and few prospective studies. Occult HBV infection clinical significance in HIV-infected patients remains unclear. HBV reactivation from occult to overt HBsAg infection can occur in immune suppression clinical setting (52), which underscores the potential clinical significance of occult $\mathrm{HBV}$ infection in HIV-positive persons. Apart from HCV infection influence on the prognosis of OHB and HIV, multiple studies have reported an association between occult HBV infection and flare-ups of hepatic transaminases (49, $53,54)$. One study found that these liver outbreaks were due to the restoration of adaptive HBV-specific immune response and innate nonspecific immune responses (55), although several other studies that compared the levels of liver enzymes in HIV patients with and without OHB were not able to confirm these response routes (51, 56-58). Longitudinal studies with longer periods of observation that examine other hepatic outcomes, such as hepatic fibrosis by liver biopsy and hepatocellular carcinoma, would provide more insight into occult HBV clinical impact in HIV-infected individuals. The literature generally advocates that, for individuals co-infected with HBV and HIV, HBsAg- positive patients should be treated if their HBV DNA, or aminotransferase levels increase, or if they experience significant hepatic fibrosis (59). Still, clear guidelines have yet to be established for occult HBV coinfection in HIV positive patients.

\subsection{Cryptogenic Cirrhosis}

Several studies have also demonstrated the presence of HBV DNA in the serum or livers of patients with cryptogenic cirrhosis, who lack serologic markers for $\mathrm{HBV}$ and $\mathrm{HCV}(34,60-63)$. The frequency of occult HBV infection in cryptogenic cirrhosis has ranged between $4.8 \%$ and $40 \%$ in various studies, depending on the prevalence of HBV in the study areas and the type of specimen studied (se- rum or liver) $(34,60,62,64)$ (Table 1$)$. OHB clinical features in these settings remain largely unknown. In the laboratory, no association was found between the presence of OHB and demographic, biochemical (AST, ALT), or serologic features in cryptogenic cirrhotic patients, implying that none of these parameters were useful to distinguish OHB-positive from OHB negative patients. However, observations showed that $\mathrm{OHB}$ frequency increased in anti-HBc positive patients isolates (regardless of anti-HBs positivity) (60-62, 64). Cirrhosis is generally considered as the most important risk factor for hepatocellular carcinoma development; therefore, in addition to its possible direct oncogenic properties, occult HBV infection may favor neoplastic transformation in infected patients through its contribution to cirrhosis.

\subsection{Hepatocellular Carcinoma (HCC)}

Despite the strong association between HCC and seropositivity of HBsAg, almost all clinical and epidemiological studies have observed HBsAg-seronegative patients affected by HCC and liver cirrhosis. A significant proportion of these patients were seropositive on anti-HBs and anti-HBc seropositive and seronegative foron antibodies against hepatitis $\mathrm{C}$ virus (anti-HCV), especially in areas where HBV infection was hyperendemic (35, 65-68). Several studies have reported HBV DNA detection in tumorous liver tissue of HBsAg- negative HCC patients, with prevalence rates ranging from $30 \%$ to $80 \%(36,69)$ (Table 1). The major question that arises with this evidence is whether occult HBV infection alone causes HCC. The hypothesis that $\mathrm{OHB}$ occult hepatitis retains the same prooncogenic features,accelerates liver disease progression, and cirrhosis development (36) has been suggested by epidemiological and molecular studies and supported by animal models. Accordingly, experiments in animal models demonstrated that both woodchucks and ground squirrels, once infected by woodchuck hepatitis virus and ground squirrel hepatitis virus, respectively, were at high risk of developing HCC after the apparent clearance of the virus $(70,71)$.

Three longitudinal follow-up studies showed the role of OHB in HCC development $(65,72,73)$. In follow-up periods of $82.8 \pm 32.6$ months, eight out of nine patients who acquired HCC were OHB positive at the time of final follow-up (73). In a similar finding, in a period of $91.8 \pm$ 48.5 months, four out of eight OHB positive cases had acquired HCC (72). However, one follow-up study found a negative correlation (74); specifically, only one of seven $\mathrm{OHB}$ and HCV co-infected patients whose HCV was not without HCV eradicated ion with interferon therapy developed HCC during average periods of $58.6 \pm 18.1$ months. Future cohort studies must be performed to address this question. Mutational analysis in HBsAg-positive HCC versus HBsAg-negative patients showed multiple genetic variants in different parts of the HBV genome and regulatory regions $(68,75,76)$; however, others did not find such 
an association (41, 77). Furthermore, in a direct examination using cassette-ligation-mediated PCR in the junctions between HBV DNA and human DNA, the integration of HBV DNA was identified in 10 out of 34 HCC patients, all of whom were OHB positive. Four of these integrations were observed in chromosome 11q (78). Altogether, clear evidence exists that OHB infection HBV maintains its pro-oncogenic properties in case of occult HBV infection, possibly by integrating with the host genome, the synthesis of pro-oncogenic proteins by free intra-hepatic HBV genomes $(33,36,47,52,64,69)$, or by progression from through cirrhosis to hepatocellular carcinoma (73). However, to reach the conclusion that OHB plays a major role in hepatocellular transformation, additional studies on molecular pathogenesis and prospective molecular epidemiological studies are needed.

\subsection{Immunosuppression}

Hepatitis, due to reactivation of HBV, is now a well-recognized complication in patients with chronic HBV infection receiving cytotoxic, corticosteroid, or immunosuppressive therapy. In these cases reactivation of the virus may occasionally be present, leading to severe or even fulminant hepatic failure sometimes indistinguishable from de novo acute infection $(34,52,79)$. Several reports have found that patients with hematological malignancies had a high carrier rate of overt HBV (i. e., HBsAg positivebetween 23.8 and $56 \%)(80,81)$. Also, evidence of previous HBV infection (especially the presence of anti$\mathrm{HBc}$ ) varies among studies, rangingfrom $37.8 \%$ to $62.5 \%$ (81-83) (Table 1). In this respect, HBV reactivation has been observed in two clinical settings: 1) advanced immune deficiency in patients with hematological-malignancy disorders, (such as acute leukemia, myeloproliferative disorders, lymphoproliferative disorders, and plasma cell dyscrasias,) at a prevalence of $3.3 \%$ to $24 \%$ (80-83); and 2) subjects who were HBsAg negative prior to chemotherapy (alkylators, antimetabolites, antitumor antibiotics, corticosteroids, etc.) who underwent treatment and transplantation (bone marrow, liver, kidney, and hematopoietic stem-cell transplantation HSCT), especially those treated with the immune suppressive rituximab (antiCD20), alemtuzumab (anti-CD52), and infliximab (antiTNF) (82-84). The rate of reactivation after chemotherapy has been reported to range between $3.3 \%$ and $4 \%$ among OHB-positive immunosuppressed patients after treatment $(82,83)$. However, there are numerous case reports of HBsAg-negative patients suffering from HBV reactivation after treatment by rituximab $(84,85)$, alemtuzumab $(86,87)$, and infliximab (as a therapeutic regimen for rheumatic and Crohn's diseases) $(88,89)$, and the number of these studies is increasing. HBV reactivation following chemotherapy can resolve, persist, recur, or lead to liver failure and death. However, viral proliferation and progression of the disease increase when patients with HBV infection immune response is suppressed by immune suppressive or cytotoxic agents. On the other hand, withdrawal of these agents leads to the immunemediated destruction of HBV-infected hepatocytes and hepatitis flares. Such flare-ups have been attributed to changes in equilibrium due to an enhanced immunological response to HBV during recovery from immune suppression $(90,91)$. In addition to the direct effects of immunosuppression, it has been indicated that the HBV genome contains a steroid-responsive DNA sequence that, when stimulated, results in an increase of HBsAg synthesis and HBV gene reactivation (92).

\subsection{Transplantation}

One of the most important clinical implications of OHB is usually observed in the setting of liver transplantation. In particular, livers from donors with OHB carry a risk of HBV transmission with infection occurring in 25-95\% of the liver grafts donated from patients who are HBsAg negative but anti-HBc positive. This infection route is indistinguishable from overt infection (9, 93-95) (Table 1). The significance of OHB in post-OLT (orthotropic liver transplantation) settings is controversial. Upon intrahepatic HBV DNA analysis, some patients show high levels of liver or serum HBV DNA and a high rate of reactivation $(96,97)$, whereas, others show low HBV-DNAHBV levels of reactivation rates $(93,98,99)$. However, it is postulated that most (if not all) researchers believe that OHB can be found in most recipients of livers from HBsAg-negative and antiHBc-positive liver donors. Studies have indicated that HBV DNA remains detectable in the serum or PBMCs of patients who are anti-HBV-positive HBV DNA positive and and HBsAg-negative for several years after removal of the HBV-infected liver (99), and extra-hepatic reservoirs serving as the source of reinfection (96). The majority of cases in these studies indicate that the tapering or withdrawal of immunosuppression occurred before reverse seroconversion (100). The likelihood of HBV reactivation would be minimized enormously by immunization and preemptive treatment with nucleos ( $\mathrm{t}$ )ide analogue drugs as a standard strategy to prevent hepatitis $B(79,101)$. The need for antiviral therapy in anti-HBcAg- positive and HBsAg-negative patients is not defined well in the literature, and the results of some studies do not support a general recommendation for preemptive use of antiviral therapy in such patients $(93,99)$. On the other hand, other empirical findings suggest that continued treatment for at least 10 years using an antiviral agent having a high resistance barrier with little or no resistance is required to achieve viral clearance while avoiding reactivation $(96,102)$. However, close monitoring of HBV DNA levels appears to be warranted.

\section{Conclusion}

Additional studies in larger cohorts of patients with long-term clinical and laboratory follow-up are warrant- 
ed to understand the biological basis and significance of occult HBV infection better, and to clarify the possible role exerted by this cryptic infection on the outcome of liver disease and hepatocellular carcinoma development. Individuals with occult HBV infection need to be monitored by follow-up studies to assess the markers of liver damage. Anti-HBc only subjects should be carefully monitored by follow-up studies to assess the significance in various clinical settings. Mass immunization of hepatitis B vaccine is important to control the transmission of HBV. Occult HBV infection is a frequent finding in cases with HIV/HCV co-infection making the virological scenario characterizing this category of patients even more complex than believed formerly. It can be expected that while the burden of chronic hepatitis B will decrease due to the introduction of more effective antiviral therapies, occult HBV infection could become a main concern.

\section{Acknowledgements}

None declared.

\section{Authors' Contribution}

None declared.

\section{Financial Disclosure}

None declared.

\section{Funding Support}

None declared.

\section{References}

1. Alavian SM, Jazayeri SM. Other views of occult hepatitis B in Hep atitis C infected patients. Eur J Intern Med. 2011;22(5):e67-8.

2. Habibollahi P, Safari S, Daryani NE, Alavian SM. Occult hepatitis $B$ infection and its possible impact on chronic hepatitis $C$ virus infection. Saudi J Gastroenterol. 2009;15(4):220-4.

3. Ramezani A, Banifazl M, Mohraz M, Rasoolinejad M, Aghakhani A. Occult hepatitis B virus infection: A major concern in HIV-infected patients. Hepat Mon. 2011;11(1):7-10.

4. Alavian SM, Nematizadeh F. Occult HBV infection in patients with serological markers of past HBV infection. Am J Gastroenterol. 2003;98(4):937-8.

5. Hollinger FB, Habibollahi P, Daneshmand A, Alavian SM. Occult Hepatitis B Infection in Chronic Hemodialysis Patients: Current Concepts and Strategy. Hepat Mon. 2010;10(3):199-204.

6. Honarkar Z, Alavian SM, Samiee S, Saeedfar K, Baladast M, Ehsani MJ, et al. Occult Hepatitis B as a cause of cryptogenic cirrhosis. Hepat Mon. 2004;4(8):155-60.

7. Hollinger FB. Hepatitis B virus infection and transfusion medicine: science and the occult. Transfusion. 2008;48(5):1001-26.

8. Mosley JW, Stevens CE, Aach RD, Hollinger FB, Mimms LT, Solomon LR, et al. Donor screening for antibody to hepatitis B core antigen and hepatitis $B$ virus infection in transfusion recipients. Transfusion. 1995;35(1):5-12.

9. Chazouilleres O, Mamish D, Kim M, Carey K, Ferrell L, Roberts JP, et al. "Occult" hepatitis B virus as source of infection in liver transplant recipients. Lancet. 1994;343(8890):142-6.

10. Allain IP, Hewitt PE, Tedder RS, Williamson LM. Evidence that anti-HBc but not HBV DNA testing may prevent some HBV transmission by transfusion. Br J Haematol. 1999;107(1):186-95.

11. Kleinman SH, Strong DM, Tegtmeier GG, Holland PV, Gorlin JB,
Cousins C, et al. Hepatitis B virus (HBV) DNA screening of blood donations in minipools with the COBAS AmpliScreen HBV test. Transfusion. 2005;45(8):1247-57.

12. Chevrier MC, St-Louis M, Perreault J, Caron B, Castilloux C, Laroche J, et al. Detection and characterization of hepatitis B virus of anti-hepatitis B core antigen-reactive blood donors in Quebec with an in-house nucleic acid testing assay. Transfusion. 2007;47(10):1794-802.

13. Kleinman SH, Kuhns MC, Todd DS, Glynn SA, McNamara A, DiMarco A, et al. Frequency of HBV DNA detection in US blood donors testing positive for the presence of anti-HBc: implications for transfusion transmission and donor screening. Transfusion. 2003;43(6):696-704

14. Liu Y, Li P, Li C, Zhou J, Wu C, Zhou YH. Detection of hepatitis B virus DNA among accepted blood donors in Nanjing, China. Virol J. 2010;7:193.

15. Yuen MF, Ka-Ho Wong D, Lee CK, Tanaka Y, Allain JP, Fung J, et al. Transmissibility of Hepatitis B Virus (HBV) Infection through Blood Transfusion from Blood Donors with Occult HBV Infection. Clin Infect Dis. 2011;52(5):624-32.

16. Bhatti FA, Ullah Z, Salamat N, Ayub M, Ghani E. Anti-hepatits B core antigen testing, viral markers, and occult hepatitis B virus infection in Pakistani blood donors: implications for transfusion practice. Transfusion. 2007;47(1):74-9.

17. Satake M, Taira R, Yugi H, Hino S, Kanemitsu K, Ikeda H, et al. Infectivity of blood components with low hepatitis B virus DNA levels identified in a lookback program. Transfusion. 2007;47(7):1197205.

18. Chen YC, Sheen IS, Chu CM, Liaw YF. Prognosis following spontaneous HBsAg seroclearance in chronic hepatitis B patients with or without concurrent infection. Gastroenterology. 2002;123(4):1084-9.

19. Carman WF, Zanetti AR, Karayiannis P, Waters J, Manzillo G, Tanzi E, et al. Vaccine-induced escape mutant of hepatitis B virus. Lancet. 1990;336(8711):325-9.

20. Ola SO, Otegbayo JA, Odaibo GN, Olaleye DO, Olubuyide IO, Summerton $\mathrm{CB}$, et al. Occult HBV infection among a cohort of Nigerian adults. IInfect Dev Ctries. 2009;3(6):442-6.

21. Cacciola I, Pollicino T, Squadrito G, Cerenzia G, Villari D, de Franchis R, et al. Quantification of intrahepatic hepatitis B virus (HBV) DNA in patients with chronic HBV infection. Hepatology. 2000;31(2):507-12.

22. Chemin I, Jeantet D, Kay A, Trepo C. Role of silent hepatitis B virus in chronic hepatitis B surface antigen(-) liver disease. Antivira Res. 2001;52(2):117-23.

23. Chaudhuri V, Tayal R, Nayak B, Acharya SK, Panda SK. Occult hepatitis B virus infection in chronic liver disease: full-length genome and analysis of mutant surface promoter. Gastroenterology. 2004;127(5):1356-71.

24. Datta S, Banerjee A, Chandra PK, Chowdhury A, Chakravarty R. Genotype, phylogenetic analysis, and transmission pattern of occult hepatitis B virus (HBV) infection in families of asymptomatic HBsAg carriers. J Med Virol. 2006;78(1):53-9.

25. Kumar GT, Kazim SN, Kumar M, Hissar S, Chauhan R, Basir SF et al. Hepatitis B virus genotypes and hepatitis B surface antigen mutations in family contacts of hepatitis B virus infected patients with occult hepatitis B virus infection. J Gastroenterol Hepatol. 2009;24(4):588-98.

26. Motta-Castro AR, Martins RM, Araujo NM, Niel C, Facholi GB, Lago $\mathrm{BV}$, et al. Molecular epidemiology of hepatitis B virus in an isolated Afro-Brazilian community. Arch Virol. 2008;153(12):2197-205.

27. Teo EK, Ostapowicz G, Hussain M, Lee WM, Fontana RJ, Lok AS Hepatitis B infection in patients with acute liver failure in the United States. Hepatology. 2001;33(4):972-6.

28. Weinberger KM, Bauer T, Bohm S, Jilg W. High genetic variability of the group-specific a-determinant of hepatitis B virus surface antigen (HBsAg) and the corresponding fragment of the viral polymerase in chronic virus carriers lacking detectable HBsAg in serum. J Gen Virol. 2000;81(Pt 5):1165-74.

29. Wagner AA, Denis F, Weinbreck P, Loustaud V, Autofage F, Rogez $S$, et al. Serological pattern 'anti-hepatitis B core alone' in HIV or hepatitis $C$ virus-infected patients is not fully explained by hepa- 
titis B surface antigen mutants. AIDS. 2004;18(3):569-71.

30. Liu CJ, Chen PJ, Chen DS. Dual chronic hepatitis B virus and hepatitis C virus infection. Hepatol Int. 2009.

31. Sagnelli E, Imparato M, Coppola N, Pisapia R, Sagnelli C, Messina $\mathrm{V}$, et al. Diagnosis and clinical impact of occult hepatitis B infection in patients with biopsy proven chronic hepatitis $\mathrm{C}$ : a multicenter study.J Med Virol. 2008;80(9):1547-53.

32. Giannini E, Ceppa P, Botta F, Fasoli A, Romagnoli P, Ansaldi F, et al. Previous hepatitis $B$ virus infection is associated with worse disease stage and occult hepatitis B virus infection has low prevalence and pathogenicity in hepatitis $\mathrm{C}$ virus-positive patients. Liver Int. 2003;23(1):12-8.

33. Brechot C, Jaffredo F, Lagorce D, Gerken G, Meyer zum Buschenfelde K, Papakonstontinou A, et al. Impact of HBV, HCV and GBVC/HGV on hepatocellular carcinomas in Europe: results of a European concerted action.J Hepatol. 1998;29(2):173-83.

34. Cacciola I, Pollicino T, Squadrito G, Cerenzia G, Orlando ME, Raimondo G. Occult hepatitis B virus infection in patients with chronic hepatitis C liver disease. NEnglJ Med. 1999;341(1):22-6.

35. Torbenson M, Thomas DL. Occult hepatitis B. Lancet Infect Dis. 2002;2(8):479-86

36. Pollicino T, Squadrito G, Cerenzia G, Cacciola I, Raffa G, Craxi A, et al. Hepatitis B virus maintains its pro-oncogenic properties in the case of occult HBV infection. Gastroenterology. 2004;126(1):102-10.

37. Minuk GY, Sun DF, Uhanova J, Zhang M, Caouette S, Nicolle LE, et al. Occult hepatitis B virus infection in a North American community-based population.J Hepatol. 2005;42(4):480-5.

38. Raimondo G. Occult hepatitis B virus infection and liver disease: fact or fiction? J Hepatol. 2001;34(3):471-3.

39. Cooper C, Kilby D. Clinical significance of hepatitis B core antibody positivity in HCV-infected and HCV/HIV coinfected individuals. Clin Infect Dis. 2004;38(9):1335-7.

40. Selim HS, Abou-Donia HA, Taha HA, El Azab GI, Bakry AF. Role of occult hepatitis B virus in chronic hepatitis $\mathrm{C}$ patients with flare of liver enzymes. Eur Intern Med. 2011;22(2):187-90.

41. Toyoda H, Kumada T, Kaneoka Y, Murakami Y. Impact of hepatitis $B$ virus (HBV) $X$ gene integration in liver tissue on hepatocellular carcinoma development in serologically HBV-negative chronic hepatitis C patients. J Hepatol. 2008;48(1):43-50.

42. Sagnelli E, Coppola N, Scolastico C, Mogavero AR, Filippini $\mathrm{P}$, Piccinino F. HCV genotype and "silent" HBV coinfection: two main risk factors for a more severe liver disease. J Med Virol. 2001;64(3):350-5.

43. Fukuda R, Ishimura N, Hamamoto S, Moritani M, Uchida Y, Ishihara S, et al. Co-infection by serologically-silent hepatitis B virus may contribute to poor interferon response in patients with chronic hepatitis $\mathrm{C}$ by down-regulation of type-I interferon receptor gene expression in the liver. J Med Virol. 2001;63(3):220-7.

44. Mrani S, Chemin I, Menouar K, Guillaud O, Pradat P, Borghi G, et al. Occult HBV infection may represent a major risk factor of nonresponse to antiviral therapy of chronic hepatitis C. J Med Virol. 2007;79(8):1075-81.

45. Raimondo G, Allain JP, Brunetto MR, Buendia MA, Chen DS, Colombo $\mathrm{M}$, et al. Statements from the Taormina expert meeting on occult hepatitis B virus infection.J Hepatol. 2008;49(4):652-7.

46. Mphahlele MJ, Lukhwareni A, Burnett RJ, Moropeng LM, Ngobeni JM. High risk of occult hepatitis B virus infection in HIV-positive patients from South Africa. J Clin Virol. 2006;35(1):14-20.

47. Gupta S, Singh S. Occult hepatitis B virus infection in ART-naive HIV-infected patients seen at a tertiary care centre in north India. BMC Infect Dis. 2010;10:53.

48. Lukhwareni A, Burnett RJ, Selabe SG, Mzileni MO, Mphahlele MJ. Increased detection of HBV DNA in HBsAg-positive and HBsAgnegative South African HIV/AIDS patients enrolling for highly active antiretroviral therapy at a Tertiary Hospital. J Med Virol. 2009;81(3):406-12.

49. Hofer M, Joller-Jemelka HI, Grob PJ, Luthy R, Opravil M. Frequent chronic hepatitis B virus infection in HIV-infected patients positive for antibody to hepatitis B core antigen only. Swiss HIV Cohort Study. Eur J Clin Microbiol Infect Dis. 1998;17(1):6-13.

50. Rodriguez-Torres M, Gonzalez-Garcia J, Brau N, Sola R, Moreno S, Rockstroh J, et al. Occult hepatitis B virus infection in the setting of hepatitis C virus (HCV) and human immunodeficiency virus (HIV) co-infection: clinically relevant or a diagnostic problem? J Med Virol. 2007;79(6):694-700.

51. Shire NJ, Rouster SD, Rajicic N, Sherman KE. Occult hepatitis B in HIV-infected patients. J Acquir Immune Defic Syndr. 2004;36(3):869-75.

52. Hu KQ. Occult hepatitis B virus infection and its clinical implications. J Viral Hepat. 2002;9(4):243-57.

53. Filippini P, Coppola N, Pisapia R, Scolastico C, Marrocco C, ZaCcariello A, et al. Impact of occult hepatitis B virus infection in HIV patients naive for antiretroviral therapy. AIDS. 2006;20(9):125360.

54. Morsica G, Ancarani F, Bagaglio S, Maracci M, Cicconi P, Cozzi Lepri A, et al. Occult hepatitis B virus infection in a Cohort of HIV-positive patients: Correlation with hepatitis C virus coinfection, virological and immunological features. Infection. 2009;37(5):445-9.

55. Benhamou Y. Antiretroviral therapy and HIV/hepatitis B virus coinfection. Clin Infect Dis. 2004;38 (Suppl 2):S98-103.

56. Lo Re V, 3rd, Frank I, Gross R, Dockter J, Linnen JM, Giachetti C, et al. Prevalence, risk factors, and outcomes for occult hepatitis B virus infection among HIV-infected patients. J Acquir Immune Defic Syndr. 2007;44(3):315-20.

57. Lo Re V, 3rd, Wertheimer B, Localio AR, Kostman JR, Dockter J, Linnen JM, et al. Incidence of transaminitis among HIV-infected patients with occult hepatitis B. J Clin Virol. 2008;43(1):32-6.

58. Nebbia G, Garcia-Diaz A, Ayliffe U, Smith C, Dervisevic S, Johnson $\mathrm{M}$, et al. Predictors and kinetics of occult hepatitis B virus infection in HIV-infected persons.J Med Virol. 2007;79(10):1464-71.

59. Soriano V, Puoti M, Peters M, Benhamou Y, Sulkowski M, Zoulim F, et al. Care of HIV patients with chronic hepatitis B: updated recommendations from the HIV-Hepatitis B Virus International Panel. AIDS. 2008;22(12):1399-410.

60. Fang Y, Teng X, Xu WZ, Li D, Zhao HW, Fu LJ, et al. Molecular characterization and functional analysis of occult hepatitis B virus infection in Chinese patients infected with genotype C. J Med Virol. 2009;81(5):826-35.

61. Chan HL, Tsang SW, Leung NW, Tse CH, Hui Y, Tam JS, et al. Occult $\mathrm{HBV}$ infection in cryptogenic liver cirrhosis in an area with high prevalence of HBV infection. Am J Gastroenterol. 2002;97(5):1211-5.

62. Hou J, Wang Z, Cheng J, Lin Y, Lau GK, Sun J, et al. Prevalence of naturally occurring surface gene variants of hepatitis B virus in nonimmunized surface antigen-negative Chinese carriers. Hepatology. 2001;34(5):1027-34.

63. Al-Mahtab M, Rahman S, Khan M. Occult Hepatitis B Virus Related Decompensated Cirrhosis of Liver in Young Males: First Report of Two Cases from Bangladesh. Hepat Mon. 2008;8(2):147-50.

64. Brechot C, Thiers V, Kremsdorf D, Nalpas B, Pol S, PaterliniBrechot P. Persistent hepatitis B virus infection in subjects without hepatitis B surface antigen: clinically significant or purely "occult"? Hepatology. 2001;34(1):194-203.

65. Ikeda K, Marusawa H, Osaki Y, Nakamura T, Kitajima N, Yamashita $\mathrm{Y}$, et al. Antibody to hepatitis B core antigen and risk for hepatitis C-related hepatocellular carcinoma: a prospective study. Ann Intern Med. 2007;146(9):649-56.

66. Raimondo G, Navarra G, Mondello S, Costantino L, Colloredo G, Cucinotta E, et al. Occult hepatitis B virus in liver tissue of individuals without hepatic disease. J Hepatol. 2008;48(5):743-6.

67. Shiota G, Oyama K, Udagawa A, Tanaka K, Nomi T, Kitamura A, et al. Occult hepatitis $B$ virus infection in HBs antigen-negative hepatocellular carcinoma in a Japanese population: involvement of HBx and p53. J Med Virol. 2000;62(2):151-8.

68. Chen CH, Changchien CS, Lee CM, Tung WC, Hung CH, Hu TH, et al. A study on sequence variations in pre-S/surface, $X$ and enhancer II/core promoter/precore regions of occult hepatitis B virus in non-B, non-C hepatocellular carcinoma patients in Taiwan. Int $J$ Cancer. 2009;125(3):621-9.

69. Paterlini P, Driss F, Nalpas B, Pisi E, Franco D, Berthelot P, et al. Persistence of hepatitis B and hepatitis C viral genomes in primary liver cancers from HBsAg-negative patients: a study of a low-endemic area. Hepatology. 1993;17(1):20-9.

70. Michalak TI, Pardoe IU, Coffin CS, Churchill ND, Freake DS, Smith 
P, et al. Occult lifelong persistence of infectious hepadnavirus and residual liver inflammation in woodchucks convalescent from acute viral hepatitis. Hepatology.1999;29(3):928-38.

71. Korba BE, Wells FV, Baldwin B, Cote PJ, Tennant BC, Popper H, et al. Hepatocellular carcinoma in woodchuck hepatitis virus-infected woodchucks: presence of viral DNA in tumor tissue from chronic carriers and animals serologically recovered from acute infections. Hepatology.1989;9(3):461-70.

72. Miura Y, Shibuya A, Adachi S, Takeuchi A, Tsuchihashi T, Nakazawa T, et al. Occult hepatitis B virus infection as a risk factor for hepatocellular carcinoma in patients with chronic hepatitis $C$ in whom viral eradication fails. Hepatol Res. 2008;38(6):546-56.

73. Squadrito G, Pollicino T, Cacciola I, Caccamo G, Villari D, La Masa $\mathrm{T}$, et al. Occult hepatitis B virus infection is associated with the development of hepatocellular carcinoma in chronic hepatitis $\mathrm{C}$ patients. Cancer. 2006;106(6):1326-30.

74. Hasegawa I, Orito E, Tanaka Y, Hirashima N, Sakakibara K, Sakurai $\mathrm{M}$, et al. Impact of occult hepatitis $\mathrm{B}$ virus infection on efficacy and prognosis of interferon-alpha therapy for patients with chronic hepatitis C. Liver Int. 2005;25(2):247-53.

75. Pollicino T, Raffa G, Costantino L, Lisa A, Campello C, Squadrito $G$, et al. Molecular and functional analysis of occult hepatitis B virus isolates from patients with hepatocellular carcinoma. Hepatology. 2007;45(2):277-85.

76. Chen BF, Liu CJ, Jow GM, Chen PJ, Kao JH, Chen DS. High prevalence and mapping of pre-S deletion in hepatitis B virus carriers with progressive liver diseases. Gastroenterology. 2006;130(4):1153-68.

77. Kusakabe A, Tanaka Y, Orito E, Sugauchi F, Kurbanov F, Sakamoto $\mathrm{T}$, et al. A weak association between occult HBV infection and non-B non-C hepatocellular carcinoma in Japan. J Gastroenterol. 2007;42(4):298-305.

78. Tamori A, Nishiguchi S, Kubo S, Enomoto M, Koh N, Takeda T, et al. Sequencing of human-viral DNA junctions in hepatocellular carcinoma from patients with HCV and occult HBV infection. Med Virol. 2003;69(4):475-81.

79. Cortelezzi A, Vigano M, Zilioli VR, Fantini NN, Pasquini MC, Deliliers GL, et al. Adefovir added to lamivudine for hepatitis B recurrent infection in refractory B-cell chronic lymphocytic leukemia on prolonged therapy with Campath-1H. J Clin Virol. 2006:35(4):467-9.

80. Chen MH, Hsiao LT, Chiou TJ, Liu JH, Gau JP, Teng HW, et al. High prevalence of occult hepatitis $B$ virus infection in patients with $B$ cell non-Hodgkin's lymphoma. Ann Hematol. 2008;87(6):475-80.

81. Ferraro D, Pizzillo P, Di Marco V, Vultaggio A, Iannitto E, Venezia $G$, et al. Evaluating the risk of hepatitis B reactivation in patients with haematological malignancies: is the serum hepatitis B virus profile reliable? Liver Int. 2009;29(8):1171-7.

82. Fukushima N, Mizuta T, Tanaka M, Yokoo M, Ide M, Hisatomi T, et al. Retrospective and prospective studies of hepatitis B virus reactivation in malignant lymphoma with occult HBV carrier. Ann Oncol. 2009;20(12):2013-7.

83. Hui CK, Cheung WW, Zhang HY, Au WY, Yueng YH, Leung AY, et al. Kinetics and risk of de novo hepatitis B infection in HBsAgnegative patients undergoing cytotoxic chemotherapy. Gastroenterology. 2006;131(1):59-68.

84. Cheung WI, Chan HL, Leung VK, Tse CH, Fung K, Lin SY, et al. Reactivation of hepatitis $B$ virus infection with persistently negative HBsAg on three HBsAg assays in a lymphoma patient undergoing chemotherapy. J Clin Virol. 2010;47(2):193-5.

85. Zhang B, Wang J, Xu W, Wang L, Ni W. Fatal reactivation of occult hepatitis $B$ virus infection after rituximab and chemotherapy in lymphoma: necessity of antiviral prophylaxis. Onkologie.
2010;33(10):537-9.

86. Hui CK, Cheung WW, Leung KW, Cheng VC, Tang BS, Li IW, et al. Retracted: outcome and immune reconstitution of HBV-specific immunity in patients with reactivation of occult HBV infection after alemtuzumab-containing chemotherapy regimen. Hepatology. 2008;48(2):1-10.

87. Iannitto E, Minardi V, Calvaruso G, Mule A, Ammatuna E, Di Trapani R, et al. Hepatitis B virus reactivation and alemtuzumab therapy. Eur J Haematol. 2005;74(3):254-8.

88. Chung SJ, Kim JK, Park MC, Park YB, Lee SK. Reactivation of hepatitis B viral infection in inactive HBsAg carriers following anti-tumor necrosis factor-alpha therapy.J Rheumatol. 2009;36(11):241620.

89. Wendling D, Di Martino V, Prati C, Toussirot E, Herbein G. Spondyloarthropathy and chronic B hepatitis. Effect of anti-TNF therapy. Joint Bone Spine. 2009;76(3):308-11.

90. Grumayer ER, Panzer S, Ferenci P, Gadner H. Recurrence of hepatitis B in children with serologic evidence of past hepatitis B virus infection undergoing antileukemic chemotherapy.J Hepatol. 1989;8(2):232-5.

91. Xunrong L, Yan AW, Liang R, Lau GK. Hepatitis B virus (HBV) reactivation after cytotoxic or immunosuppressive therapy--pathogenesis and management. Rev Med Virol. 2001;11(5):287-99.

92. Angus PW. Review: hepatitis B and liver transplantation.J Gastroenterol Hepatol.1997;12(3):217-23.

93. Ghisetti V, Marzano A, Zamboni F, Barbui A, Franchello A, Gaia $S$, et al. Occult hepatitis B virus infection in HBsAg negative patients undergoing liver transplantation: clinical significance. Liver Transpl. 2004;10(3):356-62.

94. Uemoto S, Sugiyama K, Marusawa H, Inomata Y, Asonuma K, Egawa $\mathrm{H}$, et al. Transmission of hepatitis B virus from hepatitis $B$ core antibody-positive donors in living related liver transplants. Transplantation. 1998;65(4):494-9.

95. Prieto M, Gomez MD, Berenguer M, Cordoba J, Rayon JM, Pastor $\mathrm{M}$, et al. De novo hepatitis B after liver transplantation from hepatitis B core antibody-positive donors in an area with high prevalence of anti-HBc positivity in the donor population. Liver Transpl. 2001;7(1):51-8.

96. Hussain M, Soldevila-Pico C, Emre S, Luketic V, Lok AS. Presence of intrahepatic (total and ccc) HBV DNA is not predictive of HBV recurrence after liver transplantation. Liver Transpl. 2007;13(8):113744.

97. Roche B, Feray C, Gigou M, Roque-Afonso AM, Arulnaden JL, Delvart V, et al. HBV DNA persistence 10 years after liver transplantation despite successful anti-HBS passive immunoprophylaxis. Hepatology. 2003;38(1):86-95.

98. Shetty K, Hussain M, Nei L, Reddy KR, Lok AS. Prevalence and sig nificance of occult hepatitis $B$ in a liver transplant population with chronic hepatitis C. Liver Transpl. 2008;14(4):534-40.

99. Ciesek S, Helfritz FA, Lehmann U, Becker T, Strassburg CP, Neipp $\mathrm{M}$, et al. Persistence of occult hepatitis B after removal of the hepatitis B virus-infected liver. J Infect Dis. 2008;197(3):355-60.

100. Kempinska A, Kwak EJ, Angel JB. Reactivation of hepatitis B infection following allogeneic bone marrow transplantation in a hepatitis B-immune patient: case report and review of the literature. Clin Infect Dis. 2005;41(9):1277-82.

101. Lau GK. Hepatitis B reactivation after chemotherapy: two decades of clinical research. Hepatol Int. 2008;2(2):152-62.

102. Werle-Lapostolle B, Bowden S, Locarnini S, Wursthorn K, Petersen J, Lau G, et al. Persistence of cccDNA during the natural history of chronic hepatitis $B$ and decline during adefovir dipivoxil therapy. Gastroenterology. 2004;126(7):1750-8. 